\title{
ESTIMATING THE IMPACT OF INCOME TAX ON PERSONAL SAVINGS IN SERBIA: THE TWO CHANNELS APPROACH
}

\author{
Sasa RANDJELOVIC \\ (Received: 4 October 2014; revision received: 22 March 2015; \\ accepted: 15 September 2015)
}

This paper provides an empirical evaluation of the effects of income taxation on personal savings in Serbia, by taking into account both transmitting channels: the direct impact of capital income tax on the rate-of-return and the indirect impact of labour income tax on disposable income. The estimated elasticity of bank deposits to the rate of return of 0.3 and the estimated elasticity of employment income to a labour tax wedge of -0.38 suggest that income tax function aimed at minimising the efficiency losses should not considerably differentiate the tax burden on labour and capital income. We show that in the case of the introduction of a revenue-neutral income tax, with a single marginal tax rate of $15 \%$ and considerably larger labour income exemption, households' savings in Serbia would decline by $0.27 \%$. This means that the negative impact of a rise in the capital income tax wedge on savings would prevail over the positive effects of a labour tax wedge cut. The results imply that the overall possibility to boost savings using tax policy is modest.

JEL classification indices: H22, H24, H31

Keywords: labour income tax, capital income tax, tax reform, personal savings, Taylor's model, Serbia

Sasa Randjelovic, Assistant Professor at the Faculty of Economics, University of Belgrade, Serbia. E-mail: randjelovic@ekof.bg.ac.rs 


\section{INTRODUCTION}

In the post-transition period, economic growth in Central and Eastern Europe (CEE) was mostly financed by means of FDIs and cross-border loans, since domestic savings were paltry. Starting from 2008, however, the supply of capital in the international financial markets deteriorated considerably, leading to a decline of capital inflow to these countries. Thus, the average annual FDIs in the CEE fell from 7.6\% of GDP (2001-2008) to 4.1\% of GDP (2009-2012). Cross-border loans fell from 24\% of GDP in 2008 to $17 \%$ of GDP in 2012 (European Investment Bank 2013). The same occurred in Serbia, where average annual FDIs declined from 7.1\% of GDP in the pre-crisis period to 4.9\% of GDP in 2009-2012, while cross-border loans fell from $35 \%$ to $31 \%$ of GDP. This has forced the CEE countries, including Serbia, to rely more on national savings in financing growth, which has brought the issue of savings-promotion policy measures into the focus. In that respect, it is often argued that tax policy may be an effective instrument in boosting personal savings.

The empirical literature for the OECD countries suggests that income tax has a larger negative impact on savings than consumption taxes (Tanzi - Zee 1998). According to the theory, wage tax is equivalent to consumption tax in present value terms. Consequently, the larger negative impact of income tax (compared to consumption tax) on personal savings is assigned to the effects of capital income taxation, which is why the literature on the impact of (income) taxation on personal savings was so far mostly focused on the effects of different capital income tax schemes. Under the standard theoretical framework, aggregate personal savings are treated as a function of the after-tax rate of return on savings and disposable income (Taylor 1971; Peter - Peter 2006). Capital income tax directly affects the after-tax rate of return on savings, which is why a design of capital income tax was regarded as the fundamental determinant of the savings rate for a long time. On the other hand, labour income is the single largest component of households' disposable income. Hence, the reform of labour income taxation can also affect the personal savings, since it may alter disposable income.

Although this is argued in recent theoretical literature (Diamond - Saez 2011), the empirical literature on the size of the effects of capital income tax and labour income tax on personal savings is scarce. Empirical literature on the magnitude of the impact of personal income taxation on households' savings rate mostly relates to developed countries (Bernheim 1999; Huizinga - Nicodeme 2004). According to our knowledge, the empirical literature on the effectiveness of tax policy in promoting personal savings in transition economies is limited. In addition, this question is particularly relevant to the Western Balkan countries because they faced the collapse of the banking system during the last decade of the $20^{\text {th }}$ century, 
which led to the freezing of bank deposits for years (or even decades, as was the case in Serbia). Lower confidence in the banking system caused by this experience may affect individuals' risk-taking decision patterns, influencing the overall effectiveness of tax policy tools in promoting savings in these countries.

This paper is aimed at estimating the effects of personal income taxation on personal savings in Serbia, thus contributing to the literature on the effectiveness of tax policy in boosting personal savings and capital accumulation in transition economies, with the low level of confidence and risk-adverse economic agents. In the estimation of these effects, both the impact of capital income tax and labour income tax reforms on savings are taken into account, which is novel compared to the methodology applied in the existing empirical literature, usually based only on the impact of capital income tax. These effects (of labour income and capital income taxes) will be estimated separately, in order to provide the conclusions on the optimal mix of labour-capital income taxation from the savings promotion perspective, which is the second contribution of the paper.

The paper is structured as follows. Section 2 presents the theoretical framework and literature review. Section 3 describes the current institutional setting for personal income taxation in Serbia and the reform scenario. Section 4 presents the data, the methodology, and the model. The empirical results are presented and discussed in Section 5, while Section 6 concludes.

\section{THEORETICAL FRAMEWORK AND LITERATURE REVIEW}

Unlike classical economic theory, which has regarded capital as one of the two growth drivers, neoclassical growth models (such as the Solow model) treat growth as an exogenous process, conditional on the increase of the population and technological progress, implying that capital accumulation is important only in the transition to a steady state. However, the results of empirical studies suggest that there is a strong positive relationship between capital accumulation/ savings and economic growth (Baumol 1989; Serven 2000; Chakrabarti 2006). Therefore, the fundamental question is whether (and how) policy measures could be efficient in accelerating growth by boosting capital accumulation. The view of economic theory on this issue has evolved considerably over time. The Keynesian approach relies on "absolute income hypothesis", according to which consumption is a function of real income and marginal propensity to save, implying that tax policy instruments could be efficient in promoting savings. The relationship between taxation and savings is further elaborated in the IS-LM model, which suggests that an increase in the tax rate moves the IS curve downwards, triggering reduction in the savings rate at a certain level of income. In contrast, neoclassi- 
cal economic theory has based its view on "the permanent income hypothesis" (Friedman 1957). This hypothesis is based on the assumption of a strong relationship between permanent income and permanent consumption (elasticity close to 0.9 ), which suggests a relatively low propensity to save. Under such an arrangement, the potential effects of economic policy (including tax policy) in boosting savings are limited (Peter - Peter 2006).

According to the Taylor's model (1971), aggregate savings (S) is a function of the desired amount of wealth $\left(\mathrm{W}^{*}\right)$ and the existing wealth $(\mathrm{W})$ :

$$
S=\varphi\left(W^{*}-W\right) .
$$

Desired wealth is a function of disposable income $(\mathrm{Y})$ and the rate of return $(\mathrm{R})$ :

$$
W^{*}=\beta_{1} Y+\beta_{2} R
$$

Equations (1) and (2) suggest that aggregate savings is a function of disposable income and the rate of return in the current period. This is the approach frequently used in the studies on personal savings behaviour, although other factors (e.g. uncertainty) are taken into account in some cases (Peter - Peter 2006).

Some studies based on this approach show that the difference in capital income taxation is one of the primary factors contributing to the divergence in savings rates between countries (Carroll - Summers 1987). At the same time, one of the largest disagreements in taxation theory is related to the optimal design of capital income tax. Opponents of the taxation of capital income claim that capital is an intermediary good, and as such should not be taxed (Diamond - Mirrlees 1971; Judd 1985 and Chamley 1986). Also, assuming the high elasticity of savings to required rate of return, the imposition of capital income tax could trigger a decline in the accumulation of capital, leading to slower economic growth (Mankiw et al. 2009).

Proponents of the taxation of capital income claim that the underlying assumptions for zero capital income tax are unrealistic (Diamond - Saez 2011). They suggest that it is hard to distinguish between capital and labour income in practice (e.g. in the case of self-employment) and that a cut in capital income tax requires an increase in labour taxes, which leads to an increase in inequality (since poor people more rely on labour income, while capital income is mostly earned by middle- and high-income classes). It is also pointed out that there is a positive relationship between earning ability and propensity to save, which is why the taxation of capital income could contribute to balancing between equity and efficiency, since capital income distribution properly describes the ability to earn distribution. Additionally, it is argued that when there is uncertainty related to future earnings, the taxation of capital income discourages savings, which should 
boost labour supply in the future. Chamley (1986) also argues that the taxation of capital income may be desirable since it leads to redistribution from high-income earners (who are not credit constrained), to low-income earners (who are credit constrained), thus promoting entrepreneurship. In addition, Saez (2013) proposes the progressive taxation of capital income, with a tax-exempted threshold and a single marginal tax rate, arguing that in that way, a fraction of individuals subject to capital income tax shrinks to zero. This scheme is regarded as optimal because it would trigger a decline in large fortunes until they reach exemption level, thus avoiding the infinite distortions problem associated with linear taxation.

Although the arguments in favour of zero capital income tax have been discussed for a long time, in practice only one OECD country (Estonia) has exempted capital income from taxation (Harding 2013). However, in the period from 1980 until 2005, the average tax rate on dividend and interest income in OECD countries declined from $55 \%$ to $20 \%$.

The introduction of, or the increase in, tax on savings income (interest, dividend, capital gains, etc.) leads to the decline in net (after-tax) return on savings, the size of this effect being dependent on the elasticity of savings to net return. The impact of reduction in the after-tax rate of return on savings is the result of an income and a substitution effect. While the decline in after-tax rate of return triggers rise in savings under the income effect, savings would decline under the substitution effect. Therefore, the economic theory does not provide clear conclusions on the impact of capital income taxation on savings (Feldstein 1978), which is why the answer to this question is a matter of empirical analysis. While earlier studies suggested that the substitution effect prevails (Balassa 1990), some of the more recent studies on developed countries claim that no clear conclusion on the impact of the interest rate on savings can be made (Bandiera et al. 2000), while others argue that the relationship between the interest rates and savings is positive, but rather modest (Boskin 1978; Barnheim 1999; Huizinga - Nicodeme 2004; Hondroyannis 2006). On the other hand, there is an almost general consensus in the literature on the positive impact of disposable income on personal savings (Boskin 1978; Bandiera et al. 2000; Schmidt-Hebbel - Serven 2000; Hondroyannis 2006). Most of the studies on this topic focus on developed countries, while only a few have been dealing with the developing and the CEE countries. Thus, according to Denzier et al. (2000), the determinants of personal savings behaviour in three CEE countries (Bulgaria, Hungary, and Poland) are rather similar to those in developed countries. On the other hand, Bandiera et al. (2000) concluded that savings in (seven, non-European) developing countries is less sensitive to changes in the interest rates than in developed countries. To the best of our knowledge, almost none of the empirical studies have dealt with the 
sensitivity of personal savings to changes in interest rate and disposable income in the Western Balkan countries, although this issue is specific in these countries due to the collapse of the banking system in the 1990s and the ensuing lower level of confidence/higher risk aversion of economic agents.

\section{PERSONAL INCOME TAX IN SERBIA - THE CURRENT INSTITUTIONAL SETTING AND REFORM SCENARIO}

The existing personal income tax system in Serbia is a combination of the scheduler and comprehensive income tax scheme. Within the scheduler component, incomes from various sources are taxed at the moment of receipt. All incomes are divided into eight categories, each being taxed using different rules; the statutory tax rates ranging from $10 \%$ (on self-employment and capital income) to $12 \%$ (on employment income, with a 5,000 dinars monthly exemption), $14 \%$ (on income from agriculture) and $20 \%$ (on other types of income). Due to variation in the size of exemptions, eight different effective tax rates are applied in the taxation of personal income. In addition to the tax paid at the moment of the receipt of income, individuals resident in Serbia, whose total annual income exceeds a certain threshold, are obliged to pay an annual income tax on the amount of income exceeding the threshold, at progressive rates of $10 \%$ and $15 \%$. Capital income is not subject to income tax in order to mitigate double or triple taxation. The baseline income tax scheme in Serbia is not neutral from the allocation perspective (different types of incomes are treated differently), at the same time being complex due to a variety of tax rules. Indices of horizontal and vertical equity in Serbia are considerably lower compared to other European countries (Randjelovic - Zarkovic-Rakic 2011). These are some of the frequently quoted justifications for the need for a thorough reform of the personal income tax in Serbia.

In order to estimate the impact of an income tax reform on savings, the introduction of a flat income tax scheme will be considered. Under the new tax scheme, both labour and capital income would be taxed at the marginal tax rate of $15 \%$. Labour income may be decreased by personal and dependent children allowance. Personal allowance is increased from 5,000 dinars to 9,000 dinars per month and a dependent children exemption of 4,000 dinars per month is introduced. In this manner, the statutory tax rates on labour and capital income would rise by 3 and 5 percentage points, respectively, while the exempted amount would increase by $80 \%$ or more (conditional on the number of dependents). This suggests that the overall progressivity of the income tax system would rise - Kakwani's progres- 
sivity index would rise from 0.11 to 0.18 . The reform scenario is revenue neutral, in order to ensure the comparability of the baseline and reform scenarios. ${ }^{1}$

\section{DATA, METHODOLOGY, AND MODEL SPECIFICATION}

The bulk of gross domestic savings in Serbia is generated by households, the share of corporate sector being considerably smaller, while the contribution of the government sector is negative (CLDS 2012). This is in line with the theoretical considerations according to which the personal savings rate is the determinant of the overall savings rate (Sandmo 1985). Due to a shallow financial market and underdeveloped life, and a fully-funded pension insurance, bank deposits are the key instruments of personal savings in Serbia. In November 2014, the bank deposits of the household sector in Serbia amounted to approx. 28\% of GDP. The second largest personal savings vehicles were housing mortgages, although in 2014, they were three times lower than households' bank deposits. At the same time, the total assets of life and private pension insurance funds amounted to $0.5 \%$ of GDP (National Bank of Serbia, NBS 2014), while the market capitalisation of securities traded by individuals was negligible. Bank deposits are held not only by residents of Serbia, but also by Serbians and foreigners living abroad. However, their interest income earned in Serbia is not automatically tax exempted. Some of the double taxation avoidance agreements with the countries where many Serbians live (e.g. Austria) do not prohibit Serbia to tax interest income, while in many cases, Serbians living abroad do not ask for tax exemption in Serbia since the tax rate is usually lower than in their country of residence. On the other hand, the Law on Foreign Exchange Operations prohibits residents of Serbia from keeping bank deposits abroad. The aforesaid suggests that the bank deposits can be used as a proxy for the overall personal savings in Serbia, while its dynamics could be regarded as a determinant of the overall savings rate in Serbia.

Households' response to changes in income taxation could be estimated using the micro-data (based on the cross-sectional variation between households) or aggregate macro time-series data. Since the Living Standard Measurement Survey (LSMS) 2007 does not contain the data on savings and return on savings, the impact of an income tax reform on savings will be estimated using the second approach. Starting from the economic theory (equations (1) and (2)), the evaluation of the savings effects of income tax reform is based on the estimation of bank

The revenue neutrality requirement in ex-ante analyses is elaborated and followed in numerous theoretical and empirical studies related to the analysis of the personal income tax reform (Decoster et al. 2008). 
deposits' elasticity to disposable income and to return on savings. In the next step, the impact of the changes in labour income tax on disposable income as well the impact of the changes in capital income taxation on after-tax return to savings will be estimated. By combining these results, the overall effects of income tax on savings are estimated.

Starting from equations (1) and (2), the following basic savings model is estimated:

$$
\log D E P_{t}=\beta_{0}+\beta_{1} \log I R_{t}+\beta_{2} \log W A G_{t}+\beta_{3} \log I N C_{t}+\varepsilon_{i} .
$$

We used the monthly data from January 2005 to October 2014 (118 observations). The dependent variable is the level of euro-denominated deposits in the banking sector (DEP), based on the NBS statistics. ${ }^{2}$ Interest rates (IR) offered by the banks to the households (for 1-year euro deposits) are used as a proxy for return on savings. Since the Statistical Office of Serbia does not publish monthly disposable income statistics, the data on the wage bill and other incomes are used as a proxy for disposable income. The wage bill (WAG) series is generated using the official data of the Statistical Office of Serbia on the number of employees and the monthly data of the Ministry of Finance on wage tax revenues. Households' survey data suggest that besides the wages, also remittances, pensions, and other benefits make up a considerable part (app. 46\%) of households' disposable income. Therefore, the other income (INC) variable is created, summing up remittances, pensions, and other benefits. Both the theoretical and empirical literature suggests that inflation uncertainty as well the other types of uncertainty may play an important role in savings behaviour (Taylor 1971; Wachtel 1977). Since most of the bank deposits in Serbia are Euro nominated, while Serbia was facing a large depreciation of the national currency to the euro (by app. 51\%) from January 2005 to November 2014, in addition to the basic model (3), the extended model is also estimated, taking into account the exchange rate of the Serbian dinar to the Euro $(F X)$ and the harmonised consumer price index in the euro zone (HCPI_EU):

$$
\begin{gathered}
\log D E P_{t}=\beta_{0}+\beta_{1} \log I R_{t}+\beta_{2} \log W A G_{t}+\beta_{3} \log I N C_{t}+\log F X_{t}+ \\
+\log H C P I_{-} E U_{t}+\varepsilon_{i}
\end{gathered}
$$

2 The data on euro-denominated deposits will be used since approximately $95 \%$ of households' bank deposits are denominated in euro in Serbia. 
Seasonality tests applied to the respective variables $(D E P, I R, W A G, I N C, F X$ and HCPI_EU) suggest that all variables have a seasonal component, which is why the seasonal adjustment of these series (using the Census-12 method) is performed. In order to stabilise the series and to estimate elasticity coefficients, the Box-Cox transformation has been performed.

\section{EMPIRICAL RESULTS}

\subsection{Estimation of the savings model}

The choice of the estimation method depends on the stationarity of the respective data series, which has been tested using the Augmented Dickey-Fuller (ADF), Dickey-Fuller GLS (DF-GLS), and Philips-Perron (PP) tests. The unit root tests suggest that all respective data have one unit root. ${ }^{3}$

Since all variables are I(1), the long-run elasticity of savings to interest rates and incomes may be estimated using the Engle-Granger cointegration method. Starting from the initial model specification (equations (3) and (4)), the respective elasticities are estimated using the OLS method (Table 1).

Table 1. Results of the savings model estimation using the Engle-Granger cointegration method

\begin{tabular}{lcccccc}
\hline Dep. variable & \multicolumn{5}{c}{ Indep.variables } \\
\hline logDEPt & const. & $\operatorname{logIRt}$ & $\log$ WAGt & $\operatorname{logINCt}$ & $\operatorname{logFXt}$ & logHCPI_Eut \\
Coefficients & -14.738 & 0.209 & 0.728 & 1.964 & & \\
& -14.98 & 0.317 & 0.807 & 1.747 & 0.278 & -2.502 \\
\hline
\end{tabular}

The cointegrating relationship between the variables is checked through testing the stationarity of the residuals from equation 3 (resid3) and equation 4 (resid4). ${ }^{4}$ The results of the unit root tests strongly confirm that the residuals from equations 3 and 4 are stationary, suggesting that the variables are cointegrated. Therefore, the estimated coefficients may be interpreted as a long-run relationship between the bank deposits and the explanatory variables. The coefficients suggest that the interest rate elasticity of households' deposits equals 0.21 , the elasticity to wage bill equals 0.73 , while the elasticity to the other incomes is higher, amounting to 1.96. The higher elasticity of savings to other incomes than to wages may be the

The results of the unit root tests are available upon request.

The statistical properties of the estimated model and the results of the unit root tests of the residuals are presented in Appendices 1 and 2. 
consequence of the large remittances, which are used to top-up the basic budget of the household (which is why the marginal propensity to save is larger in the case of households who receive remittances). The inclusion of the exchange rate and the euro zone inflation rate variables triggers only slight changes in the estimated elasticities - the elasticity of deposits to the interest rate rises to 0.32 , the elasticity to wages rises to 0.81 , while the elasticity to other incomes declines to 1.75. This suggests that the estimated elasticities of the savings to interest rates and wages, which are of primary interest to this paper, are robust.

An additional check of the robustness of the results is done by estimating equation (3) using the vector error correction model (VECM). Three information criteria (FPE, AIC, and HQIC) suggest that the optimal lag length is two (see Appendix 3). The Johansen procedure (using two lags) is applied to estimate the number of cointegrating vectors in equation (3). The results show that there is one cointegrating vector (see Appendix 4). Based on these results, equation (3) is estimated using the VECM approach (Table 2).

Table 2. Results of the savings model estimation using VECM

\begin{tabular}{lcccc}
\hline Dep. variable & \multicolumn{4}{c}{ Indep.variables } \\
\hline $\log$ DEP & $\operatorname{logIR}$ & $\log$ WAG & $\operatorname{logINC}$ & const. \\
Coefficients & 0.3592 & 0.6411 & 1.4192 & -16.1342 \\
Probability (p) & 0.0060 & 0.0000 & 0.0000 & \\
\hline Other statistical & chi2 $=738.8652 ; \mathrm{P}(>\operatorname{chi} 2)=0.000) ;$ \\
properties & LM test: $\mathrm{p}(\operatorname{lag}(1))=0.4650, \mathrm{p}(\operatorname{lag}(2))=0.2049$ & \\
\hline
\end{tabular}

The statistical properties of the estimated savings model using VECM are satisfactory. Lagrange multiplier test shows that there is no remaining autocorrelation (see Appendix 3). The eigenvalue stability condition test suggests that the number of cointegrating equations is properly specified and that the cointegrating equation is stationary. The results of the VECM imply that the interest elasticity of savings equals 0.36 , while the wage elasticity of savings amounts to 0.64 . The elasticities estimated using VECM are close to the elasticities estimated using the Engle-Granger procedure, which confirms the robustness of the results.

Based on the estimation of the savings model using VECM, the VEC impulse response function (IRF) is generated (Figure 1). The IRF suggests that the change to the interest rate triggers permanent changes in households' deposits.

The estimated elasticities of deposits to interest rate $(0.21,0.32$, and 0.36$)$ are within the range of estimated elasticities in the other 15 countries (ranging from 0.2 to 4.5), but being closer to the lower bound (Peter - Peter 2006). This is in accordance with the findings of Bandiera (2000), which suggest that the elasticity of savings to the interest rate in developing countries is lower than in 


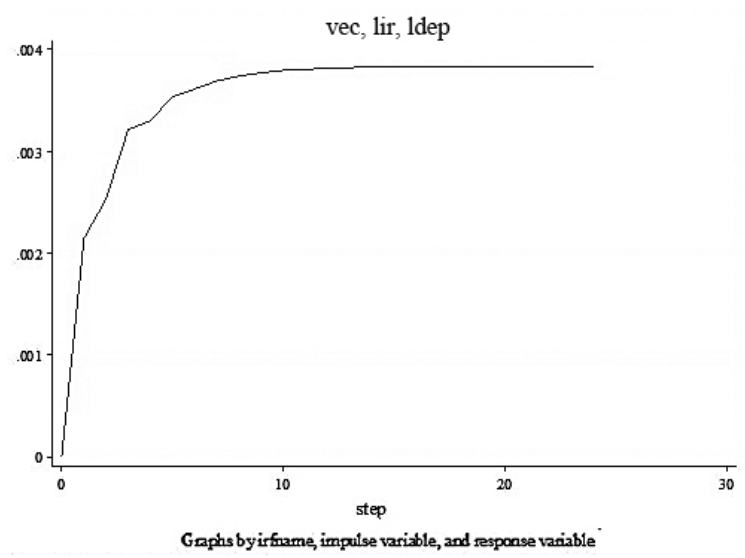

Figure 1. Impulse response of deposits to the shock in interest rate

developed countries. The lower elasticity of bank deposits to the interest rate in Serbia compared to the developed countries may be the consequence of the lower confidence of individuals in the banking sector and their higher risk aversion due to the collapse of the banking system in the 1990s and the consequent freeze of private deposits, which have been converted into public debt and are now being paid out in instalments, until 2016. In addition, the lack of viable investment alternatives in Serbia (due to a shallow financial market) may also contribute to the lower elasticity of savings to the rate of return. The estimated elasticities of bank deposits to the wage bill in Serbia $(0.64,0.73$, and 0.81$)$ are close to the results obtained in other studies (Boskin 1978; Peter - Kerr 2001).

\subsection{Estimating savings response to the personal income tax reform in Serbia}

The change in the capital income tax rate after the tax reform would trigger changes in the bank deposits, the level of changes being dependent on the size of the changes in the after-tax return to savings and the estimated elasticity of bank deposits to the interest rate. At the same time, the change in the labour income tax scheme triggers change in the labour tax wedge, which may alter employment and disposable income. Therefore, in order to evaluate the total effects of the income tax reform on savings, it is necessary to estimate the effects of both transmission channels (capital and labour income taxation) simultaneously. 
a) Estimating the effects of the capital income tax reform on savings

The change in bank deposits due to the capital income tax reform is estimated by multiplying the change in the after-tax interest rates on deposits due to the reform with the elasticity of bank deposits to the interest rate. ${ }^{5}$

Table 3. Effects of the capital income tax reform on savings

\begin{tabular}{l|c}
\hline Average after-tax interest rate - before the reform & $3.996 \%$ \\
\hline Average after-tax interest rate - after the reform & $3.885 \%$ \\
\hline Change to the effective interest rates due to the tax reform & $-2.79 \%$ \\
\hline Elasticity of bank deposits to the interest rate & 0.295 \\
\hline Long-run change in the level of bank deposits & $-0.82 \%$ \\
\hline
\end{tabular}

The results presented in Table 3 suggest that, ceteris paribus, an increase in the capital income tax rate from $10 \%$ to $15 \%$ would trigger a decline of $0.85 \%$ in the bank deposits in the long run. ${ }^{6}$

\section{b) Estimating the effects of the labour income tax reform on savings}

In Serbia, capital income and labour income are subject to taxation, while other incomes (remittances, pensions, and benefits) are tax exempted. Since employment income represents more than $5 / 6$ of the total labour income, it can be regarded as a proxy for individuals' labour income. The total employment income (wage bill) is determined by the level of employment and the average wage. In order to estimate the effects of the labour income tax reform on the wage bill, it is necessary to calculate the changes in the labour income tax wedge due to the tax reform, and to estimate the tax wedge-labour demand elasticity in Serbia. ${ }^{7}$

The change in the average tax wedge is estimated using the tax-benefit microsimulation model for Serbia (SRMOD), based on the 2007 LSMS dataset,

5 An average elasticity of 0.295 is calculated as the mean of elasticities using three different specifications of the savings model.

6 It is assumed that the change in the tax wedge would be equally shared between banks and household, i.e. $50 \%$ of the additional tax wedge would be shifted to depositors, while the remaining $50 \%$ of the increase in the tax wedge would be borne by banks.

7 Since other incomes (INC variable) are not taxable, the tax reform does not affect the disposable other income, which is why the size of the elasticity of bank deposits to other incomes has no direct impact on the results. 
encompassing 17,735 individuals. ${ }^{8}$ Parameters of the reform scenario (described in Section 3) are modelled in SRMOD and then the total tax wedge for each individual and the average tax wedge for the entire working population is computed. According to the results of microsimulation analysis, the tax reform would trigger a decline of $2.01 \%$ in the average wage tax wedge (compared to the baseline scenario). ${ }^{9}$

Since the unemployment rate in Serbia in the sample period was high (ranging from $16.1 \%$ to $23.9 \%$ ), it may be expected that the benefit from the wage tax cuts would be shifted to the employers, thus effectively affecting labour demand. In that case, the impact of the labour tax reform on total employment income can be captured by estimating the elasticity of labour demand to the wage tax wedge. The National Employment Bureau (NEB) data on the number of vacancies $(V A C)$ have been used as a proxy for labour demand. Until the end of 2008, employers in Serbia were obliged to report all vacancies to the NEB, regardless of the manner of recruitment (via NEB or via internal selection processes), which is why the sample period ends in December 2008. According to economic theory and the empirical literature, the main determinants of labour demand are labour costs (wages) and output (Carne 2007; Lewis - MacDonald 2002). In this respect, the data on GDP (in 2005 constant prices) have been used as a proxy for output, while in terms of labour costs, there were several options available. Further to the theory, labour demand could be driven by the minimum wage, labour costs, or other indicators highly correlated with them. Since the aim of this analysis is to estimate the tax wedge-labour demand elasticity, the monthly data on the average wage tax wedge have been used. Wages in Serbia are subject to income (wage) tax and social security contributions. The rules for computation have been changed several times in the sample period: the payroll tax was abolished in July 2004, the social contributions rate was increased in September 2004, a non-taxable threshold was introduced in August 2006, while the wage tax rate was reduced from $14 \%$ to $12 \%$ starting from January 2007 . In addition, the non-taxable threshold was indexed by CPI at the beginning of each following year. Since the tax wedge series $(T W)$ is highly correlated with the total labour costs and the minimum wage, the latter two are omitted from the model in order to avoid multicolinearity. Standard unit root tests (ADF, DF-GLS, and PP tests) suggest that the $V A C, G D P$, and $T W$ series have one unit root. ${ }^{10}$ Since all series

8 SRMOD is an EUROMOD-based tax-benefit microsimulation model for Serbia. For more details on SRMOD, see Randjelovic - Zarkovic (2013).

9 Although the employment income tax wedge is changed, the reform scenario is revenue neutral due to changes in the taxation of other forms of labour income (self-employment, agriculture, free-lance, etc.) and changes in the taxation of capital income.

The results of the unit root tests are available upon request. 
are I(1), the Engle-Granger cointegration method is used to estimate long-run tax wedge-labour demand elasticity, based on the following model:

$$
\log V A C_{t}=\beta_{0}+\beta_{1} \log T W_{t}+\beta_{2} \log G D P_{t}+\varepsilon_{i} .
$$

Using the sample of monthly data from January 2002 until December 2008 (84 observations), the following model has been estimated:11

$$
\log V A C_{t}=5.539-0.378 \log T W_{t}+0.749 \log G D P_{t} .
$$

Since the variables are I(1), the cointegration relationship is checked by testing the stationarity of the residuals from the estimated model (resid5). ADF, DFGLS, and PP tests show that residuals from this cointegration model are stationary (Appendix 5). Therefore, the E-G cointegration model indicates that the estimated long-run elasticity of labour demand to tax wedge equals -0.38 , while the labour demand-output elasticity equals 0.78 . The estimated labour demand elasticity is close to the results obtained in other studies, based on panel microdata (Žarković-Rakić 2010).

Since the tax reform would lead to a decline of $2.01 \%$ in the labour tax wedge, while the estimated labour demand elasticity to the tax wedge equals -0.38 , it is expected that the labour tax reform would trigger a rise of $0.76 \%$ in labour demand (Table 4).

Table 4. Effects of the labour income tax reform on savings

\begin{tabular}{l|c}
\hline Average change in the labour tax wedge due to the reform & $-2.01 \%$ \\
\hline Labour demand-tax wedge elasticity & -0.378 \\
\hline Average change in labour demand due to the reform & $0.76 \%$ \\
\hline Elasticity of bank deposits to wage bill & 0.725 \\
\hline Average change in bank deposits due to labour tax reform & $0.55 \%$ \\
\hline
\end{tabular}

Assuming that increase in labour demand would trigger an equivalent rise in the employment and wage bill (since unemployment in Serbia is demand driven), and taking into account the estimated elasticity of 0.725 of bank deposits to the wage bill, ${ }^{12}$ it is estimated that the labour tax reform would trigger a long-run increase in the bank deposits by $0.55 \%$.

11 The statistical properties of the estimated model and the results of the unit root tests of the residuals are presented in Appendices 4 and 5.

12 An average elasticity of 0.725 is calculated as the mean of elasticities using three different specifications of the savings model. 
c) Estimating the total effects of the income tax reform on savings

The overall effect of the income tax reform on savings equals the sum effects of the capital income tax reform and the labour income tax reform.

Table 5. Overall effects of the income tax reform on savings

\begin{tabular}{l|r}
\hline \multicolumn{2}{l}{ Changes of the bank deposits... } \\
\hline ..due to capital income tax reform & $-0.82 \%$ \\
\hline ..due to labour income tax reform & $0.55 \%$ \\
\hline Total & $-0.27 \%$ \\
\hline
\end{tabular}

The results presented in Table 5 suggest that the positive effects of a decline in the labour tax wedge on the households' disposable income would not be sufficient to fully offset the negative effects of the rise in the capital income tax wedge on bank deposits. Therefore, the overall effects of the revenue neutral tax reform on savings being negative - it would trigger a decline of $0.3 \%$ in the households' savings. However, these results should be interpreted with caution due to several reasons. Firstly, if capital income tax incidence is different from the one assumed in this study (50:50), the total effects could be different. Secondly, the results are highly dependent on the parameterisation of the reform scenarios. Thirdly, these results are valid only under the other-things-being-equal assumption.

\section{CONCLUDING REMARKS}

The question of the effectiveness of public policies in boosting capital accumulation is particularly important when the countries are facing limitations in respect of access to capital, a situation Serbia found itself in after 2008. It was then argued that the reform of personal income tax, which is motivated by many weaknesses of the existing tax system, could also contribute to the rise in domestic savings. According to the economic theory, domestic savings is largely determined by two groups of factors: the rate of return and personal (disposable) income. In order to assess the effectiveness of the government policy in boosting personal savings, it is necessary to capture the effects of both transmission channels. This is particularly the case for the personal income tax reform, which triggers changes in the taxation of both capital income and labour income. Empirical studies on the effects of the tax reform on savings are numerous, but most of them focused on developed countries. Consequently, there is a large gap in the empirical literature dealing with the impact of tax policy on personal savings in the CEE countries, and particularly in the Western Balkan countries. 
According to our results, the interest rate elasticity of personal savings in Serbia is modest and slightly lower than in developed countries, which could be explained by the lower level of confidence and higher risk aversion of economic agents as well by the lack of alternative savings/investment vehicles. Consequently, the possibility to stimulate savings by means of capital income tax cuts are smaller compared to developed countries, particularly when the existing capital income tax rate is low and the space for its further reduction is limited. The results also suggest that the elasticity of savings to interest rate is close to the elasticity of labour demand to the tax wedge (although slightly lower), implying that the income tax scheme aimed at minimising efficiency losses should impose a similar tax burden on labour and capital income, which is a feature of the flat tax scheme. At the same time, this is not necessarily a welfare maximising option, due to the adverse distributional effects of such tax scheme.

\section{REFERENCES}

Balassa, B. (1990): The Effects of Interest Rates on Saving in Developing Countries. Banca Nazionale del Lavoro, Quarterly Review, 172(March): 101-118.

Bandiera, O. - Caprio, G. - Honohan, P. - Schiantarelli, F. (2000): Does Financial Reform Raise or Reduce Saving? The Review of Economics and Statistics, 82(2): 239-263.

Baumol, W. (1989): Productivity and American Leadership: The Long View. MIT Press.

Bernheim, B. D. (1999): Taxation and Saving. NBER Working Paper, No. 7061.

Boskin, M. J. (1978): Taxation, Saving and the Rate of Interest. Journal of Political Economy, 86(2): 3-27.

Carne, K. (2007): Determinants of Labour Demand - Australian Experience. Queensland Government Labour Market Research Unit, Working Paper, No. 49.

Carroll, C. - Summers, L. (1987): Why have Private Savings Rates in the United States and Canada Diverged? Journal of Monetary Economics, 20(2): 249-279.

Center for Liberal and Democratic Studies - CLDS (2012): Increasing Private Domestic Savings for Serbia's Economic Growth. Belgrade. (available at: http://www.clds.rs/newsite/eng_stednja. pdf)

Chakrabarti, A. (2006): The Saving-Investment Relationship Revisited: New Evidence from Multivariate Heterogeneous Panel Cointegration Analyses. Journal of Comparative Economics, 34(2): 402-419.

Chamley, C. P. (1986): Optimal Taxation of Capital Income in General Equilibrium with Infinite Lives. Econometrica, 54(3): 607-622.

Decoster, A. - De Swerdt, K. - Orsini, K. (2010): Belgian Flat Income Tax: Effects on Labour Supply and Income Distribution. Review of Business and Economics, 55(1): $23-54$.

Denzier, C. - Wolf, H. - Ying, Y. (2000): Households Saving in Transition Economies. Policy Research Working Paper, No. 2299, The World Bank.

Diamond, P. - Mirrlees, J. (1971): Optimal Taxation and Public Production. I: Production Efficiency. American Economic Review, 61(1): 8-27.

Diamond, P. - Saez, E. (2011): The Case for a Progressive Tax: From Basic Research to Policy Recommendations. Journal of Economic Perspectives, 25(4): 165-190. 
European Investment Bank (2013): Banking in Central and Eastern Europe and Turkey - Challenges and Opportunities. EIB Report.

Feldstein, M. (1978): The Rate of Return, Taxation and Personal Savings. The Economic Journal, 88(September): 482-487.

Friedman, M. (1957): A Theory of Consumption Function. Princeton University Press, USA.

Harding, M. (2013): Taxation of Dividend, Interest and Capital Gain Income. Working Paper, No. 19 , OECD, Paris.

Hondroyannis, G. (2006): Private Saving Determinants in European Countries: A Panel Cointegration Approach. The Social Science Journal, 43(4): 553-569.

Huizinga, H. - Nicodeme, G. (2004): Are International Deposits Tax Driven? Journal of Public Economics, 88(6): 1093-1118.

Judd, K. (1985): Redistributive Taxation in a Simple Perfect Foresight Model. Journal of Public Economics, 28(1): 59-83.

Lewis, P. E. T. - MacDonald, G. (2002): The Elasticity of Demand for Labour in Australia. The Economic Record, 78(1): 18-30.

MacKinnon, J. (2010): Critical Values for Cointegration Tests. Queens Economics Department, Working Paper, No. 1227.

Mankiw, G. - Weinzierl, M. - Yagan, D. (2009): Optimal Taxation in Theory and Practice. Journal of Economic Perspectives, 23(4): 147-174.

Narodna Banka Srbije (2014): Sektor dobrovoljnih penzijskih fondova u Srbiji - izveštaj za treće tromesečje 2014. Godine (Department of the Voluntary Pension Funds in Serbia - the Report for the Third Quarter of 2014), Beograd.

Peter, V. - Kerr, I. (2001): The Influence of the Tax Mix and Tax Policy on Savings. Asia-Pacific Development Journal, 8(1): 13-40.

Peter, V. - Peter, R. (2006): Tax Finance and Savings: Conceptual Issues. International Research Journal of Finance and Economics, 3: 35-47.

Randjelovic, S. - Zarkovic-Rakic, J. (2011): Addressing Inequality and Poverty with Tax Instruments. Economic Annals, 54(19): 7-26.

Randjelovic, S. - Zarkovic-Rakic, J. (2013): Improving Working Incentives: Evaluation of Tax Policy Reform Using SRMOD. International Journal of Microsimulation, 6(1): 157-176.

Saez, E. (2013): Optimal Progressive Capital Income Taxes in the Infinite Horizon Model. Journal of Public Economics, 97(1): 61-74.

Sandmo, A. (1985): The Effects of Taxation on Saving and Risk Taking. In: Auerbach, A. J. Feldstein, M. (eds.): Handbook of Public Economics, vol. 1. North-Holland, Amsterdam, pp. 265-311.

Schmidt-Hebbel, K. - Serven, L. (2000): Does Income Inequality Raise Aggregate Saving? Journal of Development Economics, 61(2): 417-446.

Stankov, U. - Dragićević, V. (2015): Changes in the Spatial Pattern of Net Earnings: Evidence from Serbia. Acta Oeconomica, 65(3): 351-365.

Tanzi, V. - Zee, H. (1998): Taxation and the Households Savings Rate: Evidence from OECD Countries. Working Paper, No. 98/36, IMF, Washington, D.C.

Taylor, L. D. (1971): Saving out of Different Types of Income. Brookings Papers on Economic Activity, 2: 383-415.

Wachtel, P. (1977): Inflation, Uncertainty, and Saving Behaviour. NBER Explorations in Economic Research, 4: 88-108.

Žarković-Rakić, J. (2010): Uticaj visine i strukture poreskog opterećenja rada na zaposlenost: primer Srbiji (The Impact of the Size and Structure of the Labour Tax Burden on Employment: Evidence from Serbia). Doktorska disertacija, Univerzitet u Beogradu - Ekonomski fakultet. 


\section{APPENDICES}

Appendix 1. Statistical properties of the savings model (E-G approach)

\begin{tabular}{l|c|c}
\hline dependent var. & period: 2005:1-2014:10 (118 obs) \\
\hline $\log$ EEP & estimates & equation 4 \\
\hline $\operatorname{logIR}$ & 0.2090 & 0.3166 \\
\hline $\operatorname{logWAG}$ & $(0.0158)$ & $(0.0035)$ \\
\hline & 0.7284 & 0.8066 \\
\hline $\operatorname{logINC}$ & $(0.0000)$ & $(0.0000)$ \\
\hline & 1.9638 & 1.7469 \\
\hline $\operatorname{logFX}$ & $(0.0000)$ & $(0.0000)$ \\
\hline & & 0.2784 \\
\hline $\operatorname{logHCPI} E U$ & & $0.0000)$ \\
\hline const. & & -2.5019 \\
\hline & & $(0.2715)$ \\
\hline R2 & -14.7379 & -14.9800 \\
\hline adj R2 & $(0.0000)$ & $(0.0000)$ \\
\hline F-statistic & 0.9388 & 0.9406 \\
\hline Prob(F-statistic) & 0.9372 & 0.9379 \\
\hline Jarque-Bera test (p-value) & 583.0347 & 354.7966 \\
\hline
\end{tabular}

Note: Estimates are given with the corresponding p-values in parentheses. 
Appendix 2. Results of the unit root tests of the residuals from the savings model

\begin{tabular}{|c|c|c|c|c|}
\hline $\mathrm{cc}$ & & & resid3 & resid4 \\
\hline \multirow{6}{*}{$\mathrm{PP}$} & \multirow{5}{*}{$\begin{array}{l}\text { p-value } \\
\text { t-statistics } \\
\text { Test critical values: }\end{array}$} & & 0.0000 & 0.0000 \\
\hline & & & -7.6512 & -6.9517 \\
\hline & & $1 \%$ & -3.48705 & -3.48705 \\
\hline & & $5 \%$ & -2.88629 & -2.88629 \\
\hline & & $10 \%$ & -2.58005 & -2.58005 \\
\hline & Conclusion & & $\mathrm{I}(0)$ & $\mathrm{I}(0)$ \\
\hline \multirow{7}{*}{$\mathrm{ADF}$} & p-value & & 0.0000 & 0.0089 \\
\hline & t-statistics & & -7.4106 & -6.8239 \\
\hline & Test critical values: & $1 \%$ & -3.48705 & -2.58488 \\
\hline & & $5 \%$ & -2.88629 & -1.94359 \\
\hline & & $10 \%$ & -2.58005 & -1.61491 \\
\hline & MacKinnon(2010) critical values: & $1 \%$ & -4.64332 & -4.64332 \\
\hline & Conclusion & & $\mathrm{I}(0)$ & $\mathrm{I}(0)$ \\
\hline \multirow{5}{*}{ DF GLS } & t-statistics & & -6.8817 & -6.7016 \\
\hline & Test critical values: & $1 \%$ & -2.58488 & -2.58488 \\
\hline & & $5 \%$ & -1.94359 & -1.94359 \\
\hline & & $10 \%$ & -1.61491 & -1.61491 \\
\hline & Conclusion & & $\mathrm{I}(0)$ & $\mathrm{I}(0)$ \\
\hline \multicolumn{2}{|c|}{ Conclusion: } & & $\mathrm{I}(0)$ & $\mathrm{I}(0)$ \\
\hline
\end{tabular}


Appendix 3. Statistical properties of the savings model estimated using VECM

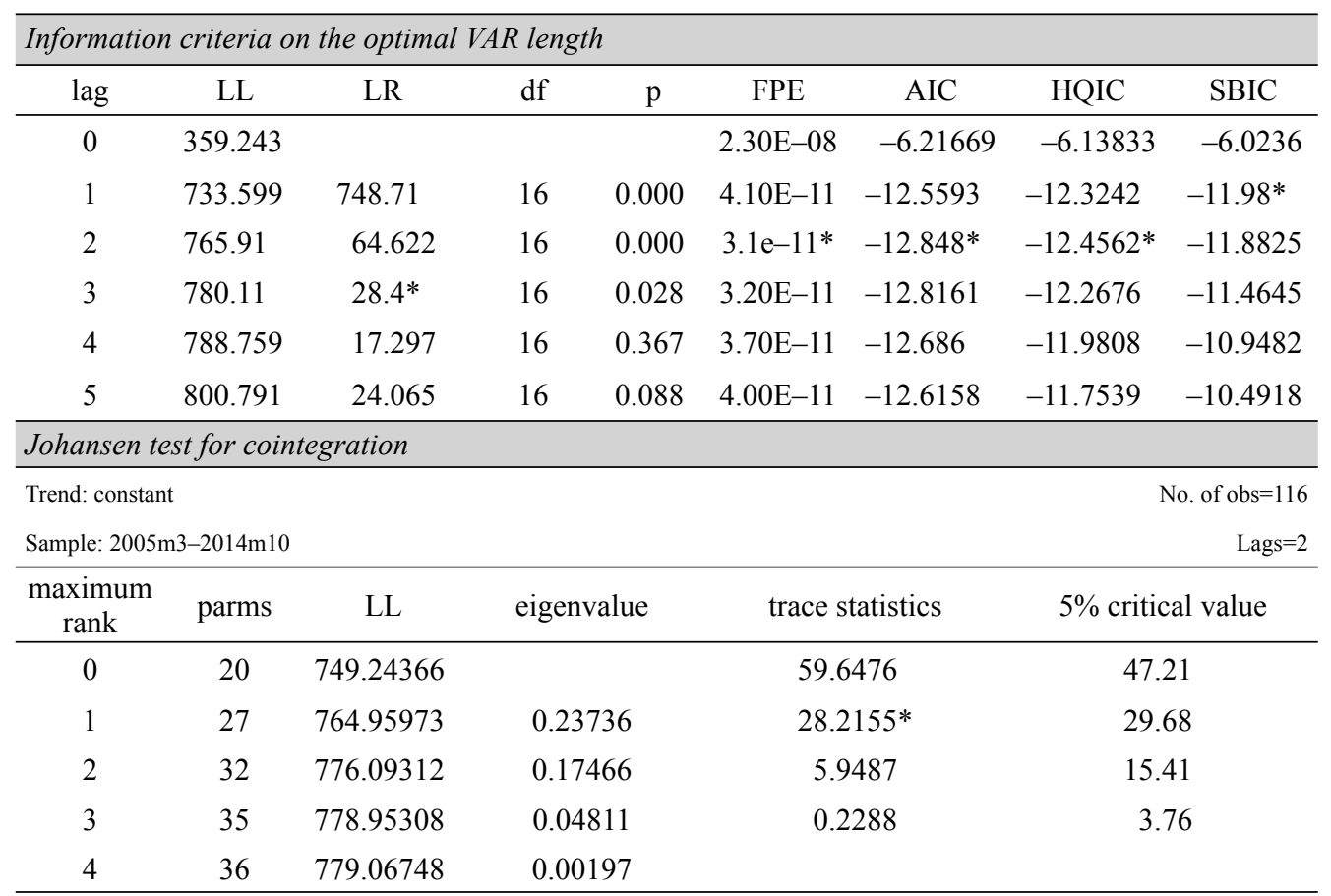

\begin{tabular}{|cc|}
\hline Eigenvalue stability condition & \\
\hline Eigenvalue & Modulus \\
\hline 1 & 1 \\
1 & 1 \\
0.6676843 & 0.667684 \\
$-0.468458+0.1983434 \mathrm{i}$ & 0.508717 \\
$-0.468458-0.1983434 \mathrm{i}$ & 0.508717 \\
$0.1171707+0.08141445 \mathrm{i}$ & 0.142679 \\
$0.1171707-0.08141445 \mathrm{i}$ & 0.142679 \\
\hline
\end{tabular}


Appendix 4. Statistical properties of the labour demand model (E-G approach)

\begin{tabular}{lccc}
\hline Dep. variable & \multicolumn{3}{c}{ Indep. variable } \\
\hline $\log V A C$ & $\log T W$ & $\log G D P$ & const. \\
\hline Coefficients & -0.378 & 0.749 & 5.539 \\
t-statistics & -1.894 & 7.308 & 6.660 \\
Probability (p) & 0.0619 & 0.0000 & 0.0000 \\
\hline \multirow{3}{*}{$\begin{array}{l}\text { Other statistical } \\
\text { properties }\end{array}$} & adj $\mathrm{R}^{2}=0.783 ; \mathrm{F}=150.5186(\mathrm{p}=0.000) ;$ \\
& Jarque-Bera test (p-value $)=0.727$, \\
& Breusch-Godfrey LM test: $\mathrm{p}=0.1812$ & \\
\hline
\end{tabular}

Appendix 5. Unit root tests of the residuals from the labour demand model

\begin{tabular}{|c|c|c|c|}
\hline & & & resid5 \\
\hline \multirow{6}{*}{$\mathrm{PP}$} & p-value & & 0.0000 \\
\hline & t-statistics & & -7.3101 \\
\hline & Test critical values: & $1 \%$ & -2.59312 \\
\hline & & $5 \%$ & -1.94476 \\
\hline & & $10 \%$ & -1.61420 \\
\hline & Conclusion & & $\mathrm{I}(0)$ \\
\hline \multirow{7}{*}{$\mathrm{ADF}$} & p-value & & 0.0000 \\
\hline & t-statistics & & -7.3172 \\
\hline & Test critical values: & $1 \%$ & -2.59312 \\
\hline & & $5 \%$ & -1.94476 \\
\hline & & $10 \%$ & -1.61420 \\
\hline & $\begin{array}{l}\text { MacKinnon(2010) critical } \\
\text { values: }\end{array}$ & $1 \%$ & -4.29374 \\
\hline & Conclusion & & $\mathrm{I}(0)$ \\
\hline \multirow{5}{*}{ DF GLS } & t-statistics & & -7.3164 \\
\hline & Test critical values: & $1 \%$ & -2.59312 \\
\hline & & $5 \%$ & -1.94476 \\
\hline & & $10 \%$ & -1.61420 \\
\hline & Conclusion & & $\mathrm{I}(0)$ \\
\hline \multicolumn{2}{|c|}{ Conclusion: } & & $\mathrm{I}(0)$ \\
\hline
\end{tabular}

